УДК 378.147:372.881

DOI:

Лариса Наконечна, кандидат філологічних наук, доиент, дочент кафедри педагогіки початкової освіти Прикарпатського національного університету імені Василя Стефаника

\title{
МОВА НОВЕЛ ВАСИЛЯ СТЕФАНИКА ЯК ЗАСІБ ФОРМУВАННЯ МОВНО-МОВЛЕННСВОЇ КОМПЕТЕНЦЇ̈ МАЙБУТНІХ УЧИТЕЛІВ ПОЧАТКОВОЇ ШКОЛИ
}

Стаття присвячена актуальному питанню формування мовно-мовленнєвої компетенції майбутніх учителів початкових класів як основи їхньої успішної професійної діяльності, зокрема в умовах діалектного мовного середовища. Автор розглядає один із засобів такої підготовки - тексти новел Василя Стефаника, класика украӥнської літератури, котрий використовував у свойй творчості діалектне мовлення жстелів Прикарпаття. Обтрунтовано необхідність використання діалектних текстів у процесі мовної підготовки майбутніх учителів початкової школи, з'ясовано навчальні можливості таких текстів, розглянуто говіркові риси мовлення персонажів Стефаника, наведено приклади опраџювання мови новел письменника у процесі підготовки студентів спеціальності “Початкова освіта" до роботи з учняи-носіями говіркового мовлення Прикарпаття.

Ключові слова: мовно-мовленнсва компетенція; професійна підготовка; майбутній учитель початкової иколи; діалектне середовище; заклад вищьӧ освіти.

Jim. 6.

Larysa Nakonechna, Ph.D.(Philology), Associate Professor of the Primary Education Pedagogy Department Vasyl Stefanyk Precarpathian National University

\section{THE LANGUAGE OF VASIL STEFANYK'S NOVELS AS A MEANS OF FORMATION OF LANGUAGE AND SPEECH COMPETENCE OF FUTURE TEACHERS OF PRIMARY SCHOOL}

The article is devoted to the topical issue of formation of language and speech competence of future primary school teachers as the basis of their successful professional activity, in particular in the conditions of dialectal language environment.

The author considers one of the means of such preparation - the texts of short stories by Vasyl Stefanyk, a classic of Ukrainian literature, who used the dialect speech of the inhabitants of Prykarpattia in his work.

The urgency of the issue is due to several factors: 1) there are no thorough scientific and methodological work on the use of dialect texts in the formation of language and speech competence of future primary school teachers for successful professional activities in a dialect environment; 2) it is necessary to clarify the educational possibilities of the dialect text as a means of forming the speech culture of future primary school teachers, as well as a means of preparing students for teaching in the dialect environment.

The article substantiates the need to use dialect texts in the process of language training of future primary school teachers and clarifies the educational possibilities of such texts.

The purpose of the article is to find out the educational possibilities of Vasyl Stefanyk's works in order to form the language and speech competence of future primary school teachers for successful professional activity in the dialect environment of Prykarpattia.

The article also considers the speech features of Stefanyk's characters, gives examples of working with the language of the writer's works in the process of preparing students majoring in "Primary Education" to work with students who speak Prykarpattia dialects.

The texts of Vasyl Stefanyk's short stories give a comprehensive description of the dialect, as they concern all language levels: phonetic, lexical-semantic, phraseological, word-forming and grammatical. This is their value for dialect and literary language.

Keywords: language and speech competence; dialect environment, professional training; future teacher, elementary school; higher education establishment.

П остановка проблеми. Мовномовленнєва компетенція $\epsilon$, безумовно, однією $з$ ключових професійних компетентностей будь-якого педагога, вчителя початкових класів зокрема. Уміння і навіть мистецтво досконалого володіння словом в усіх його виявах і можливих контекстах є однією умов, які забезпечують ефективність освітнього 


\section{МОВА НОВЕЛ ВАСИЛЯ СТЕФАНИКА ЯК ЗАСІБ ФОРМУВАННЯ МОВНО-МОВЛЕННЄВОӤ КОМПЕТЕНЦЇ МАЙБУТНІХ УЧИТЕЛІВ ПОЧАТКОВОЇ ШКОЛИ}

процесу, сприяють створенню позитивного психологічного мікроклімату, налагодженню контакту і співпраці на рівні “учитель - учень". Студенти спеціальності "Початкова освіта" як майбутні вчителі української мови в початкових класах мають досконало володіти не тільки сучасною українською мовою, але й добре знати “живе” мовлення своїх вихованців. Адже, оскільки на території України повсюдно побутує діалектне мовлення, учні початкової школи володіють насамперед місцевою мовою - мовою своїх батьків, свого оточення, меншою чи більшою мірою відмінною від літературної мови. У зв'язку 3 цим виникає потреба глибшої підготовки майбутніх учителів початкової школи до професійної діяльності у діалектному середовищі

Актуальність порушеного питання зумовлена кількома моментами: відсутністю грунтовних науково-методичних праць про використання діалектних текстів у процесі формування мовномовленнєвої компетенції майбутніх учителів початкової школи для успішної професійної діяльності в умовах діалектного середовища; потребою з'ясувати навчальні можливості діалектного тексту як засобу формування культури мовлення майбутніх учителів початкової школи, а також як засобу підготовки студентів до педагогічної діяльності в умовах діалектного середовища.

Аналіз останніх досліджень і публікацій. Проблеми формування комунікативної компетентності, мовно-мовленнєвої компетенції, професійного становлення майбутніх учителів початкової школи $\epsilon$ предметом дослідження багатьох науковців методистів. Однак питання формування мовномовленнєвої компетенції майбутніх учителів початкової школи задля успішної професійної діяльності в умовах діалектного середовища вивчені поки що недостатньо. Вагомими у цьому плані вважаємо дослідження К. Климової, Л. Симоненкової, І. Хом'яка $[2 ; 4 ; 6]$ та ін.

Мета статті - 3'ясувати навчальні можливості творів Василя Стефаника 3 метою формування мовно-мовленнєвої компетенції майбутніх учителів початкової школи задля успішної професійної діяльності в умовах діалектного середовища Прикарпаття.

Виклад основного матеріалу дослідження. Твори Василя Стефаника привертають увагу поціновувачів його творчості не тільки тематичною винятковістю, психологізмом, експресивною настроєвістю, поетизмом і стилістикою, але й своєрідністюмови. Засловами І.Матвіяса, “В. Стефаник виразно збагатив українську літературну мову елементами покутського говору” $[3,72]$.
Письменник, котрий народився, виріс і прожив більшу частину життя у с. Русів на Покутті (тепер Снятівщина Івано-Франківської області), увібрав 3 дитинства тонкощі традиційної культури, світогляду, мовлення місцевого населення і досконало відтворив все це у своїх творах.

У мовну канву новел Василя Стефаника органічно вплітаються слова 3 покутського говору південно-західного наріччя, яким він досконало володів і який був рідним, природним для покутян - прототипів героїв новеліста. Саме діалектизми якнайчіткіше відтворюють колорит тогочасного покутського села, світосприйняття і мислення селян у скрутних життєвих обставинах, надають творам трагічної тональності та експресивної насиченості.

Діалектне мовлення становить невід'ємну частину індивідуального авторського стилю письменника і $є$ однією з визначальних ознак його творчості.

Зважаючи на те, що мовлення персонажів новел Василя Стефаника - живе, функціональне і сьогодні, що елементи цього говору активно вживані в мовленні і сучасних покутян, вважаємо, що твори всесвітньо відомого новеліста-земляка можуть бути ефективним засобом підготовки майбутніх учителів початкової школи до професійної діяльності в умовах діалектного середовища.

Беремо до уваги також той факт, що, як зазначає I. Матвіяс, “унаслідок своєрідного проміжного характеру покутського говору в системі західноукраїнських діалектів його риси зрозумілі й близькі для всього західноукраїнського населення" [3, 72]. Адже “цей [покутський - Л.Н.] говір у системі діалектів південно-західного наріччя посідає особливе місце - становить тип перехідних говірок між буковинськими, гуцульськими, бойківськими, наддніпрянськими й подільськими говірками. Говірка с. Русова й сусідніх сіл найтісніше споріднюється 3 буковинськими говірками" $[3,72]$. Отож, тексти, писані більшою мірою покутським говором, узагальнено дають уявлення і про сусідні говори та говірки української мови, а відповідно, можуть знадобитися також у процесі підготовки майбутніх учителів до роботи з дітьми, котрі є їх носіями.

Тексти новел Василя Стефаника дають вичерпну характеристику покутського говору, адже стосуються усіх мовних рівнів: фонетичного, лексико-семантичного, фразеологічного словотвірного i граматичного. Водночас ці діалектизми репрезентують окремі лексико-семантичні групи, зокрема, назви предметів одягу і харчування, побуту і господарювання, віри і суспільних стосунків і т. ін. 


\section{МОВА НОВЕЛ ВАСИЛЯ СТЕФАНИКА ЯК ЗАСІБ ФОРМУВАННЯ МОВНО-МОВЛЕННСВОЙ КОМПЕТЕНЦЇ̈ МАЙБУТНІХУЧИТЕЛІВ ПОЧАТКОВОЇ ШКОЛИ}

Кожен твір Василя Стефаника дає достатньо матеріалу для спостереження над особливостями русівської говірки (складової покутського говору) і вивчення усіх перелічених лексико-семантичних груп слів та мовних рівнів.

У своїх новелах письменник вживає низку лексичних діалектизмів, як, наприклад, авус (=кінець), аді (=глянь, дивись), банувати (=тужити), бараболя (=картопля), буката (=крихта, шматок), гаравус (=геть), гезди (=осьде, тут), гиндель (=торг), дедя, дєдя (=батько), заки (=поки), клевець (=молоток), луфко (=олівець), нім (=поки), тайстра (= вишивана торба), тано (=дешево), уберія (=одяг), файно (=гарно) i багато-багато інших: “Аби єго ніхто не бачив, що плаче, то ховав голову у писану тайстру (“Стратився")".

Так, у кількох фразах головного героя новели “Синя книжечка" (наведемо нижче) натрапляємо на низку діалектизмів, зокрема і на лексичні, які варто розтлумачити, щоб адекватно зрозуміти зміст монологу: авус $=$ кінець, коби = якби, моспан = шановний добродій, пан; слимуз = слимак, гезди = тут, туск = туга, сум, жаль. “ - Продав - та й $a в y c !$ Не моє - та й решта! Ей, коби дід мій та підвівси із гроба! Моспане, штири воли, як слимузи, дваціть штири морги поля, хати на ціле село!”, “- Аби тобі так умирати легко, як мені гезди легко!”, “- - Знаєте, туск такий пішов, що раз туск!”; “ Є ще гезди гроші, але буду пити” (“Синя книжечка”).

У фразі Івана Дідуха, головного героя новели “Камінний хрест”, котрий, прощається із землею, на якій свій вік стратив, читаємо спендив: “Я на нім [горбі - Л.Н.] вік свій спендив і окалічів-єм". Цей діалектизм означає “прожити”, “промучити”, “провести” і “згайнувати”, “змарнувати”, але, очевидно, саме воно передає весь тягар важкої праці і водночас розпуку розставання із землею, омитою потом і слізьми Івана.

В іншій фразі Івана Дідуха (“Камінний хрест”) читаємо хлопєнна дівка: “- Ото-сте були хлопєнна дівка, годна-сте були”. Що то за “хлопєнна дівка"? Очевидним є спорідненість цього слова зі словом хлоп (чоловік), тобто “дівка, як хлоп”, а отже, міцна, сильна, яка у моці, праці може зрівнятися з чоловіком.

З повним переліком і значеннями використаних письменником діалектизмів (зазвичай лексичних і тих, що великою мірою відрізняються від літературних слів) можна ознайомитися у тлумачному словнику, що обов'язково додається до кожного видання творів Василя Стефаника. Інакше читачеві з-поза меж Покуття важливі деталі оповіді будуть мало зрозумілими.
Дослідники мови творів Стефаника i покутського говору стверджують, що у мовленні його персонажів збережено чимало архаїчних рис української мови, видозмінених або й відсутніх у сучасній літературній мові, але “живих” у мовленні місцевих жителів Покуття й інших регіонів західної частини України, як-от:

- форми вищого ступеня прикметників і прислівників, утворені додаванням частки май: май боязливі;

- форми майбутнього часу дієслів, утворені за допомогою таких елементів: -ко, -му, -меш, -ме, -мемо, -мете та ін., де вони вживаються після або перед дієсловом: “ ... тепер дєдя ме у рантухових сорочках ходити та жидам води доносювати...” (“Синя книжечка”); “Діти, діти, що мемо робити?” (“Лесева фамілія”); “Всі будуть дивитиси та й муть казати: аді, який Андрійко красний!”, “А кого меш бити?” (“Мамин синок");

- форми минулого часу з компонентом - $\epsilon c$, $\epsilon м,-c м u$ : “-Йду я з хати, геть цалком вже віходжу, та й поцілував-сми поріг, та й іду”; “Пропив-см усе що до нитки” (“Синя книжечка”); “ТТ читаєш у книжках, аж скаправів- $е$, то десь там воно повинно найтиси" (“У корчмі”);

- дієслівний постфікс-cя у формі $c u, c a$, вжитий у пост і препозиції: “- Та ще снив ми си недавно”, "Тут-тут утопитьси", (“Стратився”); “Камінь аби камінь, та й розпук би си із жєлю!”; “Лиш поступив-єм си, а вікна в плач” (“Синя книжечка");

- усічені форми особових займенників: го (=його), з ні (з неї), ми (=мені), ті (= тебе), $і$ (= iï), му (йому), ні (мене): "Вінесла ми хліб на дорогу, аби віт не видів”; “Сиджу я та реву, так реву, якби з ні хто паси дер” (“Синя книжечка”); "Я тебе так гірко пістувала, дула-м на $m i$, як на рану..."; "Воліла бих $m i$ на лаву лагодити" (“Виводили з села”); “Ноги $i$ посиніли від снігу, верещала як несповна розуму”; “...кервавими сльозами просила, аби $і ̈$ взєти”; “Їду до него, та знаю, що вже го не застану”; “Бувало, що озме в руки, та й горить му у тих руках” (“Стратився”); “Якби нi жінка мізинним пальцем кинула...” (“У корчмі”);

- форми двоїни іменника: “Нахилювалися до себе і відхилювалися, як би дві галузці, що ними легенький вітер колише” (“У корчмі”);

- форми дієслів умовного способу, утворені приєднанням компонентів би-м, би-с, частки бux, що співвідноситься $з$ часткою би у літературній мові: "Може би-м, яку днину посидів, а може бих, і годину не пацив...”, “...що бих чекав на шандарів, аби ні брали?” (“У корчмі”, пацити = 


\section{МОВА НОВЕЛ ВАСИЛЯ СТЕФАНИКА ЯК ЗАСІБ ФОРМУВАННЯ МОВНО-МОВЛЕННСВОӤ КОМПЕТЕНЦІЇ МАЙБУТНІХУЧИТЕЛІВ ПОЧАТКОВОЇ ШКОЛИ}

терпіти); “Лице би-с мала” (“Лесева фамілія”); “Зчєсала бих бахура, та й нема" ("Мамин синок”).

Окрім перелічених слів покутського говору, у Стефаникових текстах безліч інших фонетичних, словотвірних, граматичних діалектизмів, які так само важливо знати і “вловлювати” майбутнім учителям початкової школи, оскільки саме такі форми молодші школярі нерідко сприймають як нормативні i припускаються помилок, використовуючи їх у своєму літературному мовленні:

- фонетичні діалектизми: чєс, жєба, вчера, шестий, иего, него, єго, легонький, стів, горівка, сопівка, лужко, иулувати, хтос, якос, вес, дес та ін.,

- морфологічні (словозміна): мамов, дитинов, осіньов, дітий, очий, дітем, на дітех, мої, свої, бічи, лячи, косю, просю, радю, вчут, держут та ін.;

- словотвірні: сухонько, тихонький, люиький, панцьький, вігнати, вінести, струнва, віт, здоймити, страшіти, уздріти, озьмити, навперед та ін.

Добре знання Стефаником мовлення покутян виявляється також у майстерному використанні місцевих фразеологізмів, як-от:

“давати на відпуст” (жертвувати гроші святому, щоб допоміг у біді),

“брати туск до голови” (журитися),

“зав'єзати світ” (зробити комусь життя безрадісним),

“заперти собі гямбу” (не розмовляти, замовчати),

“не знати у котрий кут головою вдарити” (не мати притулку),

“руки зробити по лікті” (наробитися, знесиліти від важкої праці),

“у голові як коли би цигани клевцами гатили”' (про головний біль) та ін.

Відомо, що активне вживання фразеологізмів завжди надає мовленню особливої експресії, емоційності, про що свідчать і твори Василя Стефаника. Вважаємо, що і на цьому аспекті мови творів новеліста важливо наголосити і привернути до нього увагу студентів.

Надто активне використання Стефаником покутського говору не применшує вагомості його мовно-стилістичної майстерності, як і художньої значимості його новел, а навпаки, віддзеркалює тематику творів, увиразнює характер персонажів, органічно відтворює живе мовлення прототипів Стефаникових героїв. Адже, як зазначають дослідники мови творів новеліста, зокрема професори Прикарпатського національного університету імені Василя Стефаника В. Грещук і М. Лесюк, новеліст досконало володів як тогочасною літературною мовою західного варіанту, чи галицького зразка, так і місцевим діалектом. Він свідомо вклав в уста своїх героївпокутян їхнє рідне мовлення - русівську говірку, а мовлення автора подав літературною мовою. На цей “мовний дуалізм” Стефаника вперше звернув увагу один з перших дослідників мови і стилю новеліста проф. І. Ковалик, який “... доказав, що новеліст послуговувався літературною мовою для передачі авторських описів та в автобіографічних новелах, а покутський діалект укладав в уста героїв своїх творів - селян-покутян" [1, 26-27].

Виходячи з цього, можемо говорити про таке мовленнєве явище, яке виразно репрезентоване Василем Стефаником i яке у сучасному мовознавстві отримало назву “ділінгвізм" (використання мовцем залежно від ситуації або чистої літературної мови, або діалекту). Ця характеристика мовної особистості письменника теж, на наш погляд, варта уваги і наслідування, адже одне із завдань учителя-словесника, котрий працюе 3 дітьми-носіями місцевої говірки, навчити їх літературної мови, не викорінюючи з їхнього мовлення рідної говірки.

Висновки. Отож мова творів Василя Стефаника, безперечно, - один із ефективних засобів формування мовно-мовленнєвої компетенції майбутніх учителів початкової школи у процесі їх підготовки до професійної діяльності в умовах говірок південно-західного наріччя української мови. Вважаємо, що використання художніх текстів, написаних діалектами української мови чи з використанням діалектизмів, дає добрий результат не тільки у поглибленні знань студентів про діалектне мовлення, але й в опануванні ними сучасної української мови і методики навчання української мови в діалектному середовищі.

\section{ЛІТЕРАТУРА}

1. Грещук В.В. Художня мова Василя Стефаника в наукових студіях Івана Ковалика. Прикарпатський вісник НТШ Слово. 2016. № 2(34). С.25-33.

2. Климова К. Я. Готуймо майбутніх учителів початкових класів до роботи в умовах діалектного оточення. Початкова школа. №1, 2000. С. 52-53.

3. Матвіяс Іван. Роль покутського говору в мові творів Василя Стефаника. Культура слова. №72, 2010. С. 71-80.

4. Симоненкова Л. М. Вивчення фонетики i морфології в умовах місцевих говорів. Київ, 1981. 134 с.

5. Стефаник Василь. Камінний хрест: новели. Харків. Фоліо, 2006. 255 c. 


\section{НАУКОВО-МЕТОДИЧНА КОМПЕТЕНТНІСТЬ НАУКОВО-ПЕДАГОГІЧНИХПРАЦІВНИКІВ ПЕДАГОГІЧНИХЗВОУ ДІАГНОСТИЧНОМУ ВИМІРІ}

6. Хом’як І.М. Комплексний підхід до формування орфографічної компетенції. Збірник наукових праць педагогічні науки. Випуск LVIII, Частина 2, 2011. С. 127131.

\section{REFERENCES}

1. Greshchuk, V. V. (2016). Khudozhnia mova Vasylia Stefanyka v naukovykh studiiakh Ivana Kovalyka [Vasyl Stefanyk's belletristic langauge in Ivan Kovalyk's scientific studies]. Precarpathian bulletin of the Shevchenko scientific society Word. No. 2(34). pp.25-33. [in Ukrainian].

2. Klymova, K. Ya. (2000). Hotuimo maibutnikh uchyteliv pochatkovykh klasiv do roboty $\mathrm{v}$ umovakh dialektnoho otochennia [The preparation of future primary school teachers to work in a dialect environment]. Elementary School. No.1, pp. 52-53. [in Ukrainian].
3. Matviias, Ivan (2010). Rol pokutskoho hovoru v movi tvoriv Vasylia Stefanyka [The role of the Pokut dialect in the language of Vasyl Stefanyk's works]. The culture of the word. No.72, pp. 71-80. [in Ukrainian].

4. Symonenkova, L. M. (1981). Vyvchennia fonetyky i morfolohii $\mathrm{v}$ umovakh mistsevykh hovoriv [Study of phonetics and morphology in the conditions of local dialects]. Kyiv, 134 p. [in Ukrainian].

5. Stefanyk, Vasyl (2006). Kaminnyi khrest: novely ["Kaminniy Khrest": short stories]. Kharkiv, 255 p. [in Ukrainian].

6. Khomiak, I. M. (2011). Kompleksnyi pidkhid do formuvannia orfohrafichnoi kompetentsii [A comprehensive approach to the formation of spelling competence]. Collection of scientific works of pedagogical sciences. Vol. LVIII, part 2, pp. 127-131. [in Ukrainian].

Стаття надійшла до редакції 24.08.2021

УДК: 378.091.321:001.8]:005.336.2(045)

DOI:

Іван Степанець, кандидат педагогічних наук, доцент, проректор з науково-педагогічної роботи Комунального закладу “Харківська гуманітарно-педагогічна академія" Харківської обласної ради

\section{НАУКОВО-МЕТОДИЧНА КОМПЕТЕНТНІСТЬ НАУКОВО-ПЕДАГОГІЧНИХ ПРАЦІВНИКІВ ПЕДАГОГІЧНИХ ЗВО У ДІАГНОСТИЧНОМУ ВИМІРІ}

У статті акиентовано увагу на пріоритетності реалізаиії компетентнісного підходу в освіті, зокрема, в науково-методичній роботі викладача педагогічного закладу вищяої освіти (3ВО).

Визначено та проаналізовано сутність терміна “компетентнісний підхід” $i$ поняття “компетентність".

Схарактеризовано сутність $і$ значення науково-методичної компетентності в освітньому процесі в контексті ї̈ розвитку та представлено ї̈ ключові компоненти розвитку.

Висвітлено підходи до оцінювання рівня сформованості науково-методичної компетентності (НМК) на основі стандартів, пропонованих у США для очінки фахової майстерності викладачів.

Сформульовано основні критерії очінювання НМК викладача педагогічного 3 ВО відповідно до визначених напрямів ї̈ діагностики.

На підставі результатів теоретичного узагальнення $і$ досвіду в оиінюванні результативності науковометодичної роботи викладача педагогічного ЗВО, створено таблицю, щзо містить кваліметричну матрицю $i$ включає параметри, вагові показники, критерії 1 та 2 порядку, оиінку і рівень науково-методичної компетентності.

Ключові слова: компетентнісний підхі; компетентність; науково-методична компетентність; напрями діагностики; критерії оцінювання науково-методичної компетентності; освітній процес; науковометодична робота.

Puc. 2. Jim. 6.

Ivan Stepanets, Ph.D.(Pedagogy), Associate Professor, Vice-Rector for Scientific and Pedagogical Work of Municipal Establishment

"Kharkiv Humanitarian-Pedagogical Academy"of the Kharkiv Regional Council

\section{SCIENTIFIC AND METHODOLOGICAL COMPETENCE OF ACADEMIC STAFF OF PEDAGOGICAL HEI IN THE DIAGNOSTIC DIMENSION}

The article focuses on the priority of the implementation of the competence approach in education, in particular, in the scientific and methodological work of the teacher of the pedagogical HEI.

The essence of the term "competence approach" and the concept "competence" is defined and analyzed.

The essence and significance of scientific and methodological competence in the educational process in the context of its development are characterized and the key components of its development are presented. 